GRASAS Y ACEITES 69 (4)

October-December 2018, e273

ISSN-L: 0017-3495

https://doi.org/10.3989/gya.0347181

\title{
The effect of rosemary extract on 3-MCPD and glycidyl esters during frying
}

\author{
A. Yildırım and A. Yorulmaz \\ Adnan Menderes University, Faculty of Engineering, Food Engineering Department, 09100, Aydın, Turkey \\ ${ }^{\square}$ Corresponding author: asliyorulmaz@adu.edu.tr
}

Submitted: 21 March 2018; Accepted: 22 May 2018

SUMMARY: The aim of the present work was to evaluate the effect of rosemary extract (Rosmarinus Officinalis L.) on the 3-MCPD and glycidyl ester contents during deep-fat frying. Firstly, the potato samples were soaked in different concentrations of $\mathrm{NaCl}$ and they were fried in sunflower oils containing different concentrations of rosemary extract. Subsequently, repeated frying was carried out with sunflower oil enriched with rosemary extract. The frying oil and the oil extracted from potato samples were analyzed in terms of the contents of 3-MCPD and glycidyl esters according to DGF C VI 18 (10) method. The results demonstrated that the content of 3-MCPD and glycidyl esters in frying oil was not significantly affected by different $\mathrm{NaCl}$ and rosemary extract concentrations during short term frying; however, the amount of 3-MCPD esters was found to be lower for the potato crisps enriched with rosemary extract during repeated frying cycles.

KEYWORDS: 3-MCPD esters; Deep-fat frying; Glycidyl esters; Rosemary extract; Sunflower oil

RESUMEN: Efecto de extractos de romero sobre 3-MCPD y ésteres de glicidol durante frituras. El objetivo del presente trabajo fue evaluar el efecto del extracto de romero (Rosmarinus Officinalis L.) sobre los contenidos de 3-MCPD y ésteres de glicidol durante la fritura. En primer lugar, muestras de patatas se remojaron en diferentes concentraciones de $\mathrm{NaCl}$ y se frieron en aceites de girasol que contienen diferentes concentraciones de extracto de romero. Posteriormente, se realizaron frituras repetidas con aceite de girasol enriquecido con extracto de romero. El aceite de fritura y el aceite extraído de las muestras de patatas se analizaron en términos de los contenidos de 3-MCPD y ésteres de glicidol de acuerdo con el método DGF C VI 18. Los resultados demostraron que el contenido de 3-MCPD y ésteres de glicidol en el aceite de fritura no se vieron afectados significativamente por las diferentes concentraciones de $\mathrm{NaCl}$ a corto plazo, sin embargo, la cantidad de ésteres de 3-MCPD fue menor para las patatas fritas enriquecidas con extracto de romero durante los ciclos de fritura repetidas.

PALABRAS CLAVE: 3-MCPD ésteres; Aceite de girasol; Ésteres de glicidol; Extracto de romero; Fritura

ORCID ID: Ylldırım A https://orcid.org/0000-0001-5898-1209, Yorulmaz A https://orcid.org/0000-0003-4446-6585

Citation/Cómo citar este artículo: Yildırım A, Yorulmaz A. 2018. The effect of rosemary extract on 3-MCPD and glycidyl esters during frying. Grasas Aceites 69 (4), e273. https://doi.org/10.3989/gya.0347181

Copyright: (C2018 CSIC. This is an open-access article distributed under the terms of the Creative Commons Attribution 4.0 International (CC BY 4.0) License. 


\section{INTRODUCTION}

Fatty acid esters of 3-monochloro-propane1,2-diol (3-MCPD) and glycidol are known as food processing contaminants which were discovered years ago in oils and oil-containing food products. 3-MCPD esters are formed when lipids react with chlorine containing compounds at elevated temperatures (Hrncirik and Duijn, 2011). Significant amounts of 3-MCPD and glycidyl esters have been detected in refined vegetable oils, since the deodorization step of refining requires temperatures of between $240{ }^{\circ} \mathrm{C}$ and $270^{\circ} \mathrm{C}$, depending on the type of oil (Bockisch, 1993).

The maximum daily tolerable limit was established as $2 \mu \mathrm{g} / \mathrm{kg}$ body weight for free 3-MCPD (JECFA, 2001). 3-MCPD was reported to be separated from its esters in the gastrointestinal system (Bockisch, 1993). Hence, the defined limit for daily consumption in its free form was reported to be valid for the ester form. In acute studies, 3-MCPD toxicologically affected kidneys, blood, and sperm and in long-term studies, 3-MCPD led to the formation of tumors in rats (Matthäus et al., 2011). Glycidol, formed by the decomposition of glycidyl esters, is known as a probable carcinogen for humans (IARC, 2000).

Deep fat frying is a very common process used to prepare various food products with a pleasant flavor. During frying, many volatile and non-volatile compounds (Choe and Min, 2007), some of which may be toxic, are formed due to hydrolitic, thermal and oxidative reactions because the oil is exposed to high temperatures in the presence of water and air. The degradation products of frying oil, including diacylglycerols have been reported to cause the formation of glycidyl (Aniołowska and Kita, 2016) and 3-MCPD esters (Arisseto et al., 2017). It was also stated that during the frying process, the components in the frying medium may be absorbed by the fried food (Aniołowska and Kita, 2015). Different approaches, including utilization of both natural and artificial antioxidants and other additives, have been developed to prevent undesirable changes and to improve the quality and stability of frying oil (Chammem et al., 2015). The fortification of refined oils with antioxidants is commonly implemented by oil manufacturers since the antioxidants delay the undesirable changes during storage and frying operations and hence prolong shelf life of fried goods (Man and Jaswir, 2000). The use of artificial antioxidants has been limited in some countries due to possible adverse health effects (Chen et al., 1992). Therefore, plantderived natural antioxidants are gaining increasing interest. Rosemary (Rosmarinus officinalis L.) extract is the most attractive natural antioxidant due to its high thermal resistance (Man and Jaswir, 2000) and protective effect during frying (Man and Jaswir, 2000; Filip et al., 2011). Oleoresin rosemary has been determined to eliminate thermooxidative changes during frying (Upadhyay et al., 2017a). Similarly, the synergistic effect of oleoresin sage and ascorbyl palmitate has been reported to slow down the thermooxidation of sunflower oil (Upadhyay et al., 2016; Sehwag et al., 2018). Recently, electronic noise guidance has been used to determine the appropriate frying disposal time (Upadhyay et al., 2017b).

Until today, most of the research about the formation of 3-MCPD and glycidyl esters was focused on refining stages, mainly the deodorization step. However, the occurrence of these contaminants during deep-fat frying is also worth researching, since their formation mechanism is still hardly known. Moreover, the effect of different additives on the formation of 3-MCPD and glycidyl esters was restrictly researched. Zhang et al., (2016) investigated the possible mechanism of free radical scavengers, including L-ascorbyl palmitate, $\alpha$-tocopherol, lipophilic tea polyphenols and rosemary extract on the mitigation of 3-MCPD ester formation in vegetable oils and stated that all of the antioxidants decreased 3-MCPD esters in palm oil during deodorization. Li et al., (2015) proposed butylated hydroxytoluene, butylated hydroxy anisole, tert-butyl hydroquinone, propyl gallate, L-ascorbyl palmitate and $\alpha$-tocopherol as potential inhibitors of 3-MCPD esters in practice. Because the consumption of fried food products can represent an important route for human exposure to 3-MCPD (EFSA, 2016; Arisseto et al., 2017), the factors which are effective on their formation have to be deeply researched to develop effective mitigation strategies in order to reduce their daily intake. In this sense, this research was focused on the evaluation of the effect of rosemary extract on 3-MCPD and glycidyl esters formed during the deep-fat frying of potato crisps, also taking into account other compositional changes.

\section{MATERIALS AND METHODS}

\subsection{Materials and chemicals}

Sunflower oil, potatoes and dried rosemary leaves were purchased from a local market. 3-chloro1,2-propanediol, 3-chloro-1,2-propanediol-d5, glycidol, hexane, isooctane, tert-butyl methyl ether, diethyl ether, ethyl acetate, sodium methoxide, toluene, phenyl boronic acid, hydrochloric acid, methanol, $p$-anisidine, sodium hydroxide were purchased from Sigma-Aldrich (St- Louis, ABD). Sodium chloride, sodium bromide, potassium hydroxide and phenolphthalein were bought from Merck (Darmstadt, Germany).

\subsection{Methods}

Preparation of rosemary extract. The rosemary extract was obtained from ground rosemary leaves according to the Soxhlet method. Dried rosemary 
leaves of $50 \mathrm{~g}$ were weighed and placed in a soxhlet apparatus. Extraction was carried out with ethyl alcohol $(96 \%)$ for 2 hours. A rotary vacuum evaporator at $50{ }^{\circ} \mathrm{C}$ was used to evaporate the solvent. The residual extract was washed using $60 \mathrm{ml}$ of ethyl alcohol for 3 times and the solvent was removed under nitrogen atmosphere. The extract was kept in dark bottles at $-18{ }^{\circ} \mathrm{C}$ until analysis.

Deep-fat frying. The frying experiments were conducted in two steps. In the first step, potato samples were deep-fried to investigate the effects of different salt and rosemary extract concentrations. The potatoes were sliced to a thickness of $2 \mathrm{~mm} \times$ $40 \mathrm{~mm}$ and then they were kept submerged in different concentrations $(0,1,2.5$ and $5 \%)$ of sodium chloride solutions. The rosemary extract was added to frying oil at different levels $(0,500,1000$ ve 2000 $\mathrm{mg} / \mathrm{kg}$ ) just before frying. A batch of $50 \mathrm{~g}$ of potatoes was fried in $1.5 \mathrm{~kg}$ of refined sunflower oil in an electrical fryer (Remta, Turkey) for 3 minutes at $180{ }^{\circ} \mathrm{C}$. There were a total of 16 frying systems and the oil was not reused in any process. Each experiment was performed in duplicate. The oil used for the frying process and the oil extracted from potatoes were analyzed for their 3-MCPD and glycidyl ester content.

In the second step, repeated frying was carried out for 3 consecutive days for 8 hours daily with the same frying parameters $\left(180{ }^{\circ} \mathrm{C}\right.$ for 3 minutes). Before repeated frying cycles, the potato samples were soaked in distilled water for 1 hour prior to frying and subsequently fried in sunflower oil fortified with $2000 \mathrm{mg} / \mathrm{kg}$ of rosemary extract. At the end of each frying day, the fryers were shut off and the oils were filtered through filter paper to remove residuals and kept at $4{ }^{\circ} \mathrm{C}$ until the following day. The oil was replenished with rosemary-extract-added (2000 $\mathrm{mg} / \mathrm{kg}$ ) oil each day before frying. Both the fourth and eighth batches of potato chips and $50 \mathrm{ml}$ of frying oil samples were taken each day and kept at -18 ${ }^{\circ} \mathrm{C}$ until analysis.

The extraction of oil from potatoes. The oil absorbed by potatoes during frying was extracted using a semi-automatic solvent extractor (SER148, Velp Scientifica, Italy). Hexane was used as solvent and extracted oils were stored at $-18^{\circ} \mathrm{C}$ until analysis.

Determination of 3-MCPD and glycidyl ester contents. 3-MCPD and glycidyl ester analysis was carried out according to the DGF method C-VI 18 (10) (DGF, 2010) which is based on alkaline transesterification. Quantification was performed according to the method of Cheng et al., (2016) in a Shimadzu QP2020 system (Shimadzu, Kyoto, Japan) equipped with HP-5MS capillary column $(0.32 \mathrm{~mm} \times 0.25 \mu \mathrm{m}$, Agilent Technologies, USA). Samples were injected in splitless mode. The oven temperature was programmed from $80^{\circ} \mathrm{C}$ to $155^{\circ} \mathrm{C}$ at a rate of $5^{\circ} \mathrm{C} / \mathrm{min}$ and inreased to $300{ }^{\circ} \mathrm{C}$ at a rate of $15{ }^{\circ} \mathrm{C} / \mathrm{min}$, and held for $5 \mathrm{~min}$. Helium was used as carrier gas at a flow rate of $1.18 \mathrm{ml} / \mathrm{min}$. The mass spectrometer was operated in selected ion monitoring mode with positive electron ionization (EI+) at an ionization voltage of $70 \mathrm{eV}$. The temperature of the ion source and interface in the mass spectrometer was 200 and $280^{\circ} \mathrm{C}$, respectively. The ion traces $\mathrm{m} / \mathrm{z} 147$ and 150 were selected as the quantitative ions for the quantitation of 3-MCPD and 3-MCPD-d5, respectively.

Fatty acid composition. The percentage of fatty acids in frying oils was determined by capillary gas chromatography (GC 2010, Shimadzu, Kyoto, Japan) on fatty acid methyl esters obtained according to IUPAC (1987). Chromatographic separation was achieved using a DB-23 fused silica capillary column $(60 \mathrm{~m} \times 0.25 \mathrm{~mm}$ internal diameter $\mathrm{x} 0.25$ $\mu \mathrm{m}$ film thickness, J\&W Scientific). The split ratio was $80: 1$. The temperatures of the column, injector and detector were $195{ }^{\circ} \mathrm{C}, 230{ }^{\circ} \mathrm{C}$ and $240{ }^{\circ} \mathrm{C}$, respectively.

Statistical analysis. Statistical analysis was carried out using SPSS 15 statistical software (SPSS Inc., Chicago, USA). Data were evaluated by the one-way ANOVA procedure using the Duncan's multiple range test. A $p$-value of less than 0.05 was considered significant.

\section{RESULTS AND DISCUSSION}

\subsection{3-MCPD and glycidyl ester contents of frying oils and potato crips}

Deep-fat frying is one of the most widely used processes in the world for food processing. In the current study, before the frying process, the potatoes were soaked in different concentrations of sodium chloride $(\mathrm{NaCl})$, since chlorine-containing compounds are known to be the potential precursors in the formation of 3-MPCD esters (Dingel and Matissek, 2015). NaCl was chosen as the chlorinecontaining compound because it is one of the favorite seasoning and preservative agents in the food industry (Wong et al., 2017). Antioxidants have been reported to have the ability to eliminate the precursors of 3-MCPD esters such as cyclic acyloxonium free radical (CAFR) intermediates and chlorine radicals in a previously published work (Zhang et al., 2016). Hence, rosemary extract was selected as the antioxidant source because it has been widely used in foods and approved as a GRAS (Generally recognized as safe) food additive.

The influence of $\mathrm{NaCl}$ and rosemary extract on the content of 3-MCPD esters in both frying oil and potato crisps is presented in Table 1 . The total amount of 3-MCPD esters in frying oils ranged from 0.52 to $0.96 \mathrm{mg} / \mathrm{kg}$. The addition of rosemary extract did not affect the concentration of 3-MCPD esters in frying oil significantly. The influence of 
TABLE 1. The effect of rosemary extract and $\mathrm{NaCl}$ on 3-MCPD ester contents in frying oil and potato crisps $(\mathrm{mg} / \mathrm{kg})$

\begin{tabular}{lcccc}
\hline & \multicolumn{4}{c}{ Rosemary extract (mg/kg) } \\
\cline { 2 - 5 } NaCl (\%) & $\mathbf{0}$ & $\mathbf{5 0 0}$ & $\mathbf{1 0 0 0}$ & $\mathbf{2 0 0 0}$ \\
\hline \multicolumn{5}{c}{ Frying Oil } \\
0 & 0.57 & 0.96 & 0.73 & 0.80 \\
1 & 0.52 & 0.70 & 0.58 & 0.76 \\
2.5 & 0.90 & 0.76 & 0.72 & 0.71 \\
5 & 0.79 & 0.78 & 0.53 & 0.77 \\
& & Potato Crisps $^{\mathrm{a}}$ & \\
0 & $0.83^{\mathrm{a}, \mathrm{AB}}$ & $0.81^{\mathrm{a}, \mathrm{A}}$ & $1.08^{\mathrm{a}, \mathrm{AB}}$ & $1.01^{\mathrm{a}, \mathrm{A}}$ \\
1 & $0.78^{\mathrm{ab}, \mathrm{AB}}$ & $0.95^{\mathrm{ab}, \mathrm{A}}$ & $0.65^{\mathrm{a}, \mathrm{AB}}$ & $1.46^{\mathrm{b}, \mathrm{A}}$ \\
2.5 & $0.71^{\mathrm{a}, \mathrm{A}}$ & $0.85^{\mathrm{a}, \mathrm{A}}$ & $1.21^{\mathrm{a}, \mathrm{B}}$ & $0.71^{\mathrm{a}, \mathrm{A}}$ \\
5 & $1.19^{\mathrm{b}, \mathrm{B}}$ & $1.23^{\mathrm{b}, \mathrm{A}}$ & $0.36^{\mathrm{a}, \mathrm{A}}$ & $1.43^{\mathrm{b}, \mathrm{A}}$ \\
\hline
\end{tabular}

Results are reported as mean value of four replicate analyses. Different lowercase letters show differences in the same line, whereas uppercase letters indicate differences in the same column (Duncan test, $p<0.05$ ).

sodium chloride was also statistically insignificant on the content of bound 3-MCPD. However, the same tendency was not observed for potato crisps. The effects of both the $\mathrm{NaCl}$ and rosemary extract concentration were found to be statistically significant on the 3-MCPD ester contents of potatoes. The highest level of 3-MCPD esters was determined as $1.46 \mathrm{mg} / \mathrm{kg}$; whereas the lowest level was detected to be $0.36 \mathrm{mg} / \mathrm{kg}$ in crisps. The changes in $\mathrm{NaCl}$ concentration were found to be statistically significant when the samples were fortified with $1000 \mathrm{mg} /$ $\mathrm{kg}$ rosemary extract compared to when rosemary extract was not added prior to frying.

The results on the effect of $\mathrm{NaCl}$ and rosemary extract on the content of glycidyl esters are presented in Table 2. The glycidyl ester contents vary between 0.19 and $0.48 \mathrm{mg} / \mathrm{kg}$ for frying oils. The differences between the different concentrations of $\mathrm{NaCl}$ were not significant during deep-fat frying, as was stated by Wong et al. (2017). The content of glycidyl esters in potato crips ranged from 0.15 and $0.41 \mathrm{mg} / \mathrm{kg}$. The results given in Table 2 indicate that both $\mathrm{NaCl}$ and rosemary extract were not influential on the content of glycidyl esters. The content of glycidyl esters were generally found to be lower than 3-MCPD esters for both frying oils and oils extracted from potatoes. The non-formation of glycidyl esters can be attributed to the low frying temperature in accordance with different studies in the literature which point out that the content of glycidyl esters increases dramatically when the temperature is higher than $230{ }^{\circ} \mathrm{C}$ (Zelinková et al., 2006; Matthäus and Pudel, 2015).

Table 3 shows the changes in 3-MCPD and glycidyl ester levels during repeated frying at seven different points in time: $0,4,8,12,16,20$ and 24 hours. The content of ester-bound 3-MCPD of sunflower oil (SO) ranged from 0.42 and $1.01 \mathrm{mg} / \mathrm{kg}$; whereas
TABLE 2. The effect of rosemary extract and $\mathrm{NaCl}$ on glycidyl ester contents in frying oil and potato crisps $(\mathrm{mg} / \mathrm{kg})$

\begin{tabular}{lcccc}
\hline & \multicolumn{4}{c}{ Rosemary extract (mg/kg) } \\
\cline { 2 - 5 } NaCl (\%) & $\mathbf{0}$ & $\mathbf{5 0 0}$ & $\mathbf{1 0 0 0}$ & $\mathbf{2 0 0 0}$ \\
\hline \multirow{4}{*}{ Frying Oil } \\
1 & 0.39 & 0.20 & 0.29 & 0.22 \\
2.5 & 0.27 & 0.36 & 0.47 & 0.24 \\
5 & 0.21 & 0.33 & 0.27 & 0.21 \\
& 0.48 & 0.19 & 0.36 & 0.39 \\
0 & & Potato Crisps & \\
1 & 0.29 & 0.33 & 0.24 & 0.22 \\
2.5 & 0.15 & 0.25 & 0.31 & 0.30 \\
5 & 0.18 & 0.18 & 0.21 & 0.21 \\
\hline
\end{tabular}

Results are reported as mean value of four replicate analyses. Different lowercase letters show differences in the same line, whereas uppercase letters indicate differences in the same column (Duncan test, $p<0.05$ ).

it was between 0.42 and $0.79 \mathrm{mg} / \mathrm{kg}$ for sunflower oil enriched with rosemary extract (SOR). There was no statistically significant change in the content of 3-MCPD esters of either SO or SOR as the frying time increased. The changes in the concentration of ester-linked 3-MCPD esters detected in the oil samples extracted from potatoes are presented in Table 3 in order to evaluate the carry-over of the compounds due to fat uptake. The amount of $3-\mathrm{MCPD}$ esters was in the range of $0.56-0.94 \mathrm{mg} / \mathrm{kg}$ for $\mathrm{SO}$, while it was in the range of $0.19-0.64 \mathrm{mg} / \mathrm{kg}$ for SOR. The content of 3-MCPD esters was mainly lower for SOR, which may point to the inhibitory effect of rosemary extract on 3-MCPD levels during repeated frying. Generally, it can be noted that 3-MCPD esters were transferred from the frying medium to the fried product in accordance with the results of Arisseto et al., (2017) who found that 3-MCPD esters have the ability to be transferred from frying oil to fried material during the deep-fat frying of various food stuffs.

The content of glycidyl esters in the frying oils were in the range of $0.06-0.37 \mathrm{mg} / \mathrm{kg}$ for SO and $0.07-0.37 \mathrm{mg} / \mathrm{kg}$ for SOR. The concentration of glycidyl esters in SO changed significantly with frying time. At the end of 8, 12, 20, and 24 hours of frying, the glycidyl ester contents in SOR were lower than SO. Additionally, the increase in glycidyl esters at 8,12 and 24 hours was statistically significant for SO. Wong et al., (2017) reported the trend for glycidyl esters to increase during prolonged frying. However, there are also contradictory reports which have shown a decrease in the concentration 
TABLE 3. The effect of rosemary extract and $\mathrm{NaCl}$ on 3-MCPD and glycidyl ester contents in frying oil and potato crisps during repeated frying $(p<0.05)$.

\begin{tabular}{|c|c|c|c|c|}
\hline \multirow[b]{2}{*}{ Frying time (h) } & \multicolumn{2}{|c|}{$\begin{array}{c}\text { 3-MCPD esters } \\
\text { (mg/kg) }\end{array}$} & \multicolumn{2}{|c|}{$\begin{array}{l}\text { Glycidyl Esters } \\
\text { (mg/kg) }\end{array}$} \\
\hline & SO & SOR & SO & SOR \\
\hline \multicolumn{5}{|c|}{ Frying Oil } \\
\hline 0 & 0.59 & 0.59 & $0.37^{\mathrm{A}, \mathrm{x}}$ & $0.37^{\mathrm{A}, \mathrm{x}}$ \\
\hline 4 & 0.98 & 0.64 & $0.06^{\mathrm{A}, \mathrm{x}}$ & $0.11^{\mathrm{A}, \mathrm{x}}$ \\
\hline 8 & 0.80 & 0.65 & $0.27^{\mathrm{CD}, \mathrm{y}}$ & $0.12^{\mathrm{A}, \mathrm{x}}$ \\
\hline 12 & 1.01 & 0.79 & $0.31^{\mathrm{DE}, \mathrm{y}}$ & $0.07^{\mathrm{A}, \mathrm{x}}$ \\
\hline 16 & 0.53 & 0.73 & $0.06^{\mathrm{A}, \mathrm{x}}$ & $0.07^{\mathrm{A}, \mathrm{x}}$ \\
\hline 20 & 0.42 & 0.42 & $0.14^{\mathrm{B}, \mathrm{x}}$ & $0.12^{\mathrm{A}, \mathrm{x}}$ \\
\hline 24 & 0.82 & 0.56 & $0.20^{\mathrm{BC}, \mathrm{y}}$ & $0.07^{\mathrm{A}, \mathrm{x}}$ \\
\hline \multicolumn{5}{|c|}{ Potato Crisps } \\
\hline 4 & $0.89^{\mathrm{y}}$ & $0.59^{x}$ & $0.19^{\mathrm{A}, \mathrm{x}}$ & $0.14^{\mathrm{x}}$ \\
\hline 8 & $0.80^{\mathrm{x}}$ & $0.64^{\mathrm{x}}$ & $0.19^{\mathrm{A}, \mathrm{x}}$ & $0.13^{x}$ \\
\hline 12 & $0.75^{\mathrm{x}}$ & $0.56^{\mathrm{x}}$ & $0.13^{\mathrm{A}, \mathrm{x}}$ & $0.14^{\mathrm{x}}$ \\
\hline 16 & $0.94^{x}$ & $0.60^{\mathrm{x}}$ & $0.07^{\mathrm{A}, \mathrm{x}}$ & $0.16^{\mathrm{x}}$ \\
\hline 20 & $0.56^{\mathrm{x}}$ & $0.53^{\mathrm{x}}$ & $0.16^{\mathrm{A}, \mathrm{x}}$ & $0.34^{x}$ \\
\hline 24 & $0.83^{\mathrm{x}}$ & $0.19^{\mathrm{x}}$ & $0.45^{\mathrm{B}, \mathrm{y}}$ & $0.16^{\mathrm{x}}$ \\
\hline
\end{tabular}

Results are reported as mean value of four replicate analyses. Different uppercase letters indicate differences in the same column, whereas " $\mathrm{x}-\mathrm{y}$ " show the differences between SO and SOR (Duncan test, $p<0.05$ ), SO: sunflower oil, SOR: sunflower oil containing rosemary extract

of glycidyl esters during prolonged deep-fat frying (Aniołowska and Kita, 2015; Hammouda et al., 2017; Aniołowska and Kita, 2016). In general, the concentration of glycidyl esters in potato crisps did not change significantly when rosemary extract was added to the frying oil.

\subsection{Fatty acid composition of frying oils}

The changes in fatty the acid composition of the frying oil during repeated frying are given in Table 4. Sunflower oil showed a typical fatty acid composition including $56.89 \%$ linoleic, $34.03 \%$ oleic, $5.97 \%$ palmitic and $2.91 \%$ stearic acids as is common for most sunflower oils (Sánchez-Gimeno et al., 2008; Filip et al., 2011). There was an obvious reduction in linoleic acid, with a consequent increase in the contents of oleic acid and palmitic acids as reported by Romero et al., (2000) and Casal et al., (2010). The content of linolenic acid decreased with frying time. There was not a significant difference between sunflower and rosemary extract containing sunflower oil in terms of fatty acid distribution as was also previously reported by Filip et al., (2011).

\section{CONCLUSIONS}

The results of the study show that the effects of sodium chloride and fortification of frying oil with rosemary extract were statistically insignificant on the formation of 3-MCPD and glycidyl esters in frying oil during the deep-fat frying of potato crisps. However the bound 3-MCPD content in the oil extraction showed statistically significant alterations. The concentration of glycidyl esters was always lower than 3-MCPD esters throughout the frying process. In addition, the amount of 3-MCPD esters was higher in the potato oils, while the amount of glycidyl esters was generally higher in the frying oils. With regards

TABLE 4. The changes in fatty acid composition of frying oils during repeated frying (\%)

\begin{tabular}{|c|c|c|c|c|c|c|c|c|c|}
\hline \multirow{2}{*}{$\begin{array}{l}\text { Frying } \\
\text { time (h) }\end{array}$} & \multirow[b]{2}{*}{ Oil type } & \multicolumn{8}{|c|}{ Fatty acid composition (\%) } \\
\hline & & C 16:0 & C 16:1 & C 17:0 & C 17:1 & C 18:0 & C 18:1 & C 18:2 & C 18:3 \\
\hline \multirow[t]{2}{*}{0} & SO & $5.97^{\mathrm{A}, \mathrm{x}}$ & $0.13^{\mathrm{AB}, \mathrm{x}}$ & $0.01^{\mathrm{A}, \mathrm{x}}$ & $0.01^{\mathrm{A}, \mathrm{x}}$ & $2.91^{\mathrm{B}, \mathrm{x}}$ & $34.03^{\mathrm{A}, \mathrm{x}}$ & $56.89^{\mathrm{C}, \mathrm{x}}$ & $0.05^{\mathrm{A}, \mathrm{x}}$ \\
\hline & SOR & $5.97^{\mathrm{a}, \mathrm{x}}$ & $0.13^{\mathrm{b}, \mathrm{x}}$ & $0.01^{\mathrm{a}, \mathrm{x}}$ & $0.01^{\mathrm{a}, \mathrm{x}}$ & $2.91^{\mathrm{ab}, \mathrm{x}}$ & $34.03^{\mathrm{a}, \mathrm{x}}$ & $56.89^{\mathrm{e}, \mathrm{x}}$ & $0.05^{\mathrm{a}, \mathrm{x}}$ \\
\hline \multirow[t]{2}{*}{4} & SO & $6.01^{\mathrm{A}, \mathrm{x}}$ & $0.08^{\mathrm{A}, \mathrm{x}}$ & $0.01^{\mathrm{A}, \mathrm{x}}$ & $0.01^{\mathrm{A}, \mathrm{x}}$ & $2.85^{\mathrm{AB}, \mathrm{x}}$ & $34.87^{\mathrm{B}, \mathrm{x}}$ & $56.15^{\mathrm{C}, \mathrm{x}}$ & $0.05^{\mathrm{A}, \mathrm{x}}$ \\
\hline & SOR & $6.18^{\mathrm{b}, \mathrm{x}}$ & $0.14^{\mathrm{bc}, y}$ & $0.02^{\mathrm{ab}, \mathrm{y}}$ & $0.01^{\mathrm{a}, \mathrm{x}}$ & $3.00^{\mathrm{ab}, \mathrm{x}}$ & $34.68^{\mathrm{b}, \mathrm{x}}$ & $55.93^{\mathrm{d}, \mathrm{x}}$ & $0.04^{\mathrm{a}, \mathrm{x}}$ \\
\hline \multirow[t]{2}{*}{8} & SO & $6.40^{\mathrm{B}, \mathrm{x}}$ & $0.07^{\mathrm{A}, \mathrm{x}}$ & $0.09^{\mathrm{A}, \mathrm{x}}$ & $0.10^{\mathrm{A}, \mathrm{x}}$ & $2.75^{\mathrm{A}, \mathrm{x}}$ & $35.91^{\mathrm{C}, \mathrm{x}}$ & $55.82^{\mathrm{C}, \mathrm{x}}$ & $0.04^{\mathrm{A}, \mathrm{x}}$ \\
\hline & SOR & $6.27^{\mathrm{b}, \mathrm{x}}$ & $0.08^{\mathrm{ab}, \mathrm{x}}$ & $0.02^{\mathrm{ab}, \mathrm{x}}$ & $0.01^{\mathrm{A}, \mathrm{x}}$ & $2.82^{\mathrm{a}, \mathrm{x}}$ & $36.08^{\mathrm{c}, \mathrm{x}}$ & $54.69^{\mathrm{c}, \mathrm{x}}$ & $0.04^{\mathrm{a}, \mathrm{x}}$ \\
\hline \multirow[t]{2}{*}{12} & SO & $6.53^{\mathrm{BC}, \mathrm{x}}$ & $0.12^{\mathrm{AB}, \mathrm{y}}$ & $0.03^{\mathrm{A}, \mathrm{x}}$ & $0.02^{\mathrm{A}, \mathrm{x}}$ & $3.25^{\mathrm{C}, \mathrm{x}}$ & $36.24^{\mathrm{C}, \mathrm{x}}$ & $53.79^{\mathrm{B}, \mathrm{x}}$ & $0.04^{\mathrm{A}, \mathrm{x}}$ \\
\hline & SOR & $6.32^{\mathrm{b}, \mathrm{y}}$ & $0.05^{\mathrm{a}, \mathrm{x}}$ & $0.01^{\mathrm{a}, \mathrm{x}}$ & $0.01^{\mathrm{a}, \mathrm{x}}$ & $3.05^{\mathrm{ab}, \mathrm{x}}$ & $36.17^{\mathrm{c}, \mathrm{x}}$ & $54.35^{\mathrm{c}, \mathrm{y}}$ & $0.04^{a, x}$ \\
\hline \multirow[t]{2}{*}{16} & SO & $6.76^{\mathrm{CD}, \mathrm{x}}$ & $0.16^{\mathrm{B}, \mathrm{y}}$ & $0.11^{\mathrm{A}, \mathrm{x}}$ & $0.12^{\mathrm{A}, \mathrm{x}}$ & $3.28^{\mathrm{C}, \mathrm{x}}$ & $36.91^{\mathrm{D}, \mathrm{x}}$ & $52.80^{\mathrm{B}, \mathrm{x}}$ & $0.24^{\mathrm{A}, \mathrm{x}}$ \\
\hline & SOR & $6.60^{\mathrm{c}, \mathrm{x}}$ & $0.11^{\mathrm{bc}, \mathrm{x}}$ & $0.02^{\mathrm{ab}, \mathrm{x}}$ & $0.01^{\mathrm{a}, \mathrm{x}}$ & $3.22^{\mathrm{ab}, \mathrm{x}}$ & $37.14^{\mathrm{d}, \mathrm{y}}$ & $52.87^{\mathrm{b}, \mathrm{x}}$ & $0.09^{a, x}$ \\
\hline \multirow[t]{2}{*}{20} & SO & $6.78^{\mathrm{CD}, \mathrm{x}}$ & $0.12^{\mathrm{AB}, \mathrm{x}}$ & $0.03^{\mathrm{A}, \mathrm{x}}$ & $0.02^{\mathrm{A}, \mathrm{y}}$ & $3.12^{\mathrm{BC}, \mathrm{x}}$ & $37.25^{\mathrm{D}, \mathrm{x}}$ & $52,68^{\mathrm{B}, \mathrm{x}}$ & $0.03^{\mathrm{A}, \mathrm{x}}$ \\
\hline & SOR & $6.68^{\mathrm{c}, \mathrm{x}}$ & $0.16^{\mathrm{c}, \mathrm{y}}$ & $0.02^{\mathrm{ab}, \mathrm{x}}$ & $0.01^{\mathrm{a}, \mathrm{x}}$ & $2.83^{\mathrm{a}, \mathrm{x}}$ & $37.31^{\mathrm{d}, \mathrm{x}}$ & $52.71^{\mathrm{b}, \mathrm{x}}$ & $0.03^{\mathrm{a}, \mathrm{x}}$ \\
\hline \multirow[t]{2}{*}{24} & SO & $6.95^{\mathrm{D}, \mathrm{x}}$ & $0.18^{\mathrm{B}, \mathrm{y}}$ & $0.02^{\mathrm{A}, \mathrm{x}}$ & $0.01^{\mathrm{A}, \mathrm{x}}$ & $3.35^{\mathrm{C}, \mathrm{x}}$ & $38.28^{\mathrm{C}, \mathrm{x}}$ & $51.17^{\mathrm{A}, \mathrm{x}}$ & $0.04^{\mathrm{A}, \mathrm{y}}$ \\
\hline & SOR & $6.75^{\mathrm{c}, \mathrm{x}}$ & $0.11^{\mathrm{bc}, \mathrm{x}}$ & $0.02^{\mathrm{b}, \mathrm{x}}$ & $0.01^{\mathrm{a}, \mathrm{x}}$ & $3.25^{\mathrm{b}, \mathrm{x}}$ & $38.28^{\mathrm{e}, \mathrm{x}}$ & $51.54^{\mathrm{a}, \mathrm{y}}$ & $0.03^{\mathrm{a}, \mathrm{x}}$ \\
\hline
\end{tabular}

Results are reported as mean value of four replicate analyses.

The different uppercase letters (A-D) show differences for sunflower oil (SO); lowercase letters (a-e) indicate differences for sunflower oil enriched with rosemary extract (SOR); and lowercase letters (x-y) indicate differences between SO and SOR in the same line during repeated frying (Duncan test, $p<0.05$ ). 
to repeated frying, the content of 3-MCPD esters was in general higher in non-fortified samples. Moreover, during repeated frying, the maximum levels of 3-MCPD and glycidyl ester contents were detected in the oil samples which were not fortified with rosemary extract when compared to enriched oils. From this point of view, the results allow for the assertion that the rosemary extract might have a potential to minimize the formation of 3-MCPD and glycidyl esters under repeated frying conditions at certain frying times. Considering potato oils during repeated frying, on the other hand, the frying duration was generally not influential on the formation of 3-MCPD and glycidyl esters. However the content of 3-MCPD esters was always lower in oil samples fortified with rosemary extract. Considering the scarce reports on the effect of different antioxidants on the occurrence of 3-MCPD and glycidyl esters in the literature, the current data reported herein may be useful to fill the gap in the literature. Further studies can focus on researching the effects of novel antioxidants from various sources on 3-MCPD and glycidyl ester formation and the mechanisms of antioxidants on the 3-MCPD and glycidyl ester contents should also be clarified.

\section{ACKNOWLEDGEMENTS}

This research was supported by Research Fund of the Adnan Menderes University. Project number: MF-17016.

\section{Conflict of interest}

The authors declare that there is no conflict of interest.

\section{REFERENCES}

Aniołowska M, Kita A. 2015. The effect of type of oil and degree of degradation on glycidyl Esters content during the frying of French fries. J. Am. Oil Chem. Soc. 92, 1621-1631. https://doi.org/10.1007/s11746-015-2715-3

Aniołowska M, Kita A. 2016. The effect of frying on glycidyl esters content in palm oil. Food Chem. 203, 95-103. https://doi. org/10.1016/j.foodchem.2016.02.028

Arisseto AP, Marcolino PFC, Augusti AC, Scaranelo GR, Berbari SAG, Miguel AM, Morgano MA, Vicente E. 2017. Contamination of Fried Foods by 3-Monochloropropane-1, 2-diol Fatty Acid Esters During Frying. J. Am. Oil Chem. Soc. 94, 449-455. https://doi. org/10.1007/s11746-017-2951-9

Bockisch M. 1993. Nahrungsfette und-öle, Handbuch der Lebensmitteltechnologie. Eugen Ulmer GmbH \& Co, Stuttgart Hohenheim.

Casal S, Malheiro R, Sendas A, Oliveira BP, Pereira JA. 2010. Olive oil stability under deep-frying conditions. Food Chem. Toxicol. 48, 2972-2979. https://doi.org/10.1016/j. fct. 2010.07 .036

Chammem N, Saoudi S, Sifaoui I, Sifi S, de Person, M, Abderraba M, Moussa F, Hamdi M. 2015. Improvement of vegetable oils quality in frying conditions by adding rosemary extract. Ind. Crop Prod. 74, 592-599. https://doi. org/10.1016/j.indcrop.2015.05.054
Cheng W, Liu G, Liu X. 2016. Formation of glycidyl fatty acid esters both in real edible oils during laboratory-scale refining and in chemical model during high temperature exposure. J. Agr. Food Chem. 64, 5919-5927. https://doi. org/10.1021/acs.jafc.6b01520

Choe E, Min DB. 2007. Chemistry of deep-fat frying oils. $J$. Food Sci. 72, 77-86. https://doi.org/10.1111/j.1750-3841. 2007.00352.x

Deutsche Gesellschaft für Fettwissenschaft (DGF). 2010. DGFStandard method C-VI 18 (10) Fatty-acid-bound 3-chloropropane-1,2-diol (3-MCPD) and 2,3-epoxi-propane-1-ol (glycidol) Determination in oils and fats by GC/MS.

Dingel A, Matissek R. 2015. Esters of 3-monochloropropane-1, 2-diol and glycidol: no formation by deep frying during large-scale production of potato crisps. Eur. Food Res. Technol. 241, 719-723. https://doi.org/10.1007/ s00217-015-2491-1

EFSA (2016). Risks for human health related to the presence of 3- and 2-monochloropropanediol (MCPD), and their fatty acid esters, and glycidyl fatty acid esters in food. EFSA J 14:4426.

Filip S, Hribar J, Vidrih R. 2011. Influence of natural antioxidants on the formation of trans- fatty- acid isomers during heat treatment of sunflower oil. Eur. J. Lipid Sci. Tech. 113, 224-230. https://doi.org/10.1002/ejlt.200900231

Hammouda IB, Zribi A, Mansour AB, Matthäus B, Bouaziz, M. 2017. Effect of deep-frying on 3-MCPD esters and glycidyl esters contents and quality control of refined olive pomace oil blended with refined palm oil. Eur. Food Res. Technol. 243, 1219-1227. https://doi.org/10.1007/ s00217-016-2836-4

Hrncirik K, van Duijn G. 2011. An initial study on the formation of 3-MCPD esters during oil refining. Eur. J. Lipid Sci. Tech. 113, 374-379. https://doi.org/10.1002/ejlt.201000317

IARC. 2000. IARC monographs on the evaluation of carcinogenic risks to humans, some industrial chemicals, IARC Monographs. 469-486.

International Union of Pure and Applied Chemistry. 1987. Standard methods for analysis of oils, fats and derivates (7th ed.), IUPAC Method 2.301. Palo Alto, CA: Blackwell Scientific Publications.

Joint FAO/ WHO Expert Committee on Food Additives. 2001. Summary of the Fifty-seventh Meeting of the Joint FAO/ WHO Expert Committee on Food Additives (JECFA), Rome, 5-14 June, pp. 20-24.

Li C, Jia H, Shen M, Wang Y, Nie S, Chen Y, Zhou Y, Wang Y, Xie M. 2015. Antioxidants inhibit formation of 3-monochloropropane-1, 2-diol esters in model reactions. J. Agr. Food Chem. 63, 9850-9854. https://doi.org/10.1021/acs. jafc. 5 b03503

Man YBC, Jaswir, I. 2000. Effect of rosemary and sage extracts on frying performance of refined, bleached and deodorized (RBD) palm olein during deep-fat frying. Food Chem. 69, 301-307. https://doi.org/10.1016/S0308-8146(99)00270-8

Matthäus B, Pudel F, Fehling P, Vosmann K, Freudenstein A. 2011. Strategies for the reduction of 3-MCPD esters and related compounds in vegetable oils. Eur. J. Lipid Sci. Tech. 113, 380-386. https://doi.org/10.1002/ejlt.201000300

Matthäus B, Pudel F. 2015. Mitigation of MCPD and glycidyl esters in edible oils. Processing Contaminants in Edible Oils: MCPD and Glycidyl Esters, 23.

Romero A, Cuesta C, Sánchez-Muniz FJ. 2000. Trans fatty acid production in deep fat frying of frozen foods with different oils and frying modalities. Nutr. Res. 20, 599-608. https:// doi.org/10.1016/S0271-5317(00)00150-0

Sánchez-Gimeno AC, Negueruela AI, Benito M, Vercet A, Oria R. 2008. Some physical changes in Bajo Aragón extra virgin olive oil during the frying process. Food Chem. 110, 654-658. https://doi.org/10.1016/j.foodchem.2008.02.057

Sehwag S, Upadhyay R, Mishra HN. 2017. Assessment of thermo-oxidative rancidity in sunflower oil and fried potato chips stabilised with oleoresin sage (Salvia officinalis L.) and ascorbyl palmitate by altered triglycerides and electronic nose. Int. J. Food Sci. Tech. 53, 1211-1218. https://doi.org/10.1111/ijfs. 13698 
Upadhyay R, Mishra HN. 2016. Multivariate optimization of a synergistic blend of oleoresin sage (Salvia officinalis L.) and ascorbyl palmitate to stabilize sunflower oil. J. Food Technol. 53, 1919-1928. https://doi.org/10.1007/ s13197-015-2157-9

Upadhyay R, Sehwag S, Mishra HN. 2017a. Chemometric approach to develop frying stable sunflower oil blends stabilized with oleoresin rosemary and ascorbyl palmitate. Food Chem. 218, 496-504. https://doi.org/10.1016/j. foodchem.2016.09.105

Upadhyay R, Sehwag S, Mishra HN. 2017b. Electronic nose guided determination of frying disposal time of sunflower oil using fuzzy logic analysis. Food Chem. 221, 379-385. https://doi.org/10.1016/j.foodchem.2016.10.089
Wong YH, Lai OM, Abas F, Nyam KL, Nehdi IA, Muhamad H, Tan CP. 2017. Factors Impacting the Formation of 3-MCPD Esters and Glycidyl Esters During Deep Fat Frying of Chicken Breast Meat. J. Am. Oil Chem. Soc. 94, 759-765. https://doi.org/10.1007/s11746-017-2991-1

Zelinková Z, Svejkovská B, Velíšek J, Doležal M. 2006. Fatty acid esters of 3-chloropropane-1, 2-diol in edible oils. Food Addit. Contam. 23, 1290-1298. https://doi. org/10.1080/02652030600887628

Zhang H, Jin P, Zhang M, Cheong LZ, Hu P, Zhao Y, Yu L, Wang Y, Jiang Y, Xu X. 2016. Mitigation of 3-monochloro-1, 2-propanediol ester formation by radical scavengers. J. Agr. Food Chem. 64, 5887-5892. https://doi. org/10.1021/acs.jafc.6b02016 